\title{
UPAYA MENINGKATKAN AKTIVITAS BELAJAR MELALUI MODEL PEMBELAJARAN KOOPERATIF LEARNING TIPE JIGSAW PADA MATERI PERKEMBANGAN SISTEM PERIODIK UNSUR
}

\author{
Reni Vinolia \\ Dinas Pendidikan Aceh Tamiang, SMA Negeri 1 Manyak Payed \\ Jl. Tualang Baru, Manyak Payed, Aceh Tamiang, 24471 \\ Email: renivinolia@gmail.com
}

\begin{abstract}
Abstrak
Penelitian ini bertujuan untuk mengetahui aktivitas dan hasil belajar siswa kelas X.1 SMA Negeri 1 Manyak Payed dalam pembelajaran kimia dengan menggunakan model pembelajaran kooperatif learning tipe jigsaw pada pokok perkembangan sistem periodik unsur. Penelitian dilakukan dengan menggunakan metode penelitian tindakan kelas (PTK). Instrument dalam penelitian ini terdiri dari 5 soal essay yang digunakan untuk mengukur hasil belajar siswa dan lembar observasi yang digunakan untuk melihat aktivitas siswa.

Subjek yang digunakan dalam penelitian adalah siswa kelas X.I SMA Negeri 1 Manyak Payed yang terdiri dari 32 siswa. Hasil yang diperoleh dalam penelitian ini menunjukkan rata-rata aktivitas belajar siswa adalah $72,30 \%$ pada siklus I dan hasil belajar pada siklus II nilai rata-ratanya adalah $83,07 \%$ terjadi peningkatan 12,9\%. 2. Dari segi proses dan segi hasil terjadi peningkatan hasil belajar, hal ini dapat dilihat dari hasil tes pada siklus I dengan rata-ratanya75,3 dan hasil pada siklus II rata-ratanya 82,2 terjadi peningkatan sebesar 6,9 atau 8,4\% . 3.Hal ini membuktikan bahwa dengan menggunakan metode Jigsaw dalam pembelajaran, siswa dapat menjadi lebih aktif dan keaktifan yang dilakukan siswa adalah keadaan yang sesuai dengan tujuan pembelajaran. Disimpulkan bahwa metode Jigsaw dapat memberikan hasil afektif yang sangat berguna bagi anak didik, dimana siswa dididik untuk dapat bertanggung jawab dan bekerja sama dalam hal yang positif.
\end{abstract}

Kata kunci: Model Kooperatif, Jigsaw, Aktivitas Belajar, Hasil Belajar, Sistem Periodik Unsur

\begin{abstract}
This study aims to determine the activities and learning outcomes of class X.1 students of SMA Negeri 1 Manyak Payed in chemistry learning by using a jigsaw cooperative learning model on the principal development of the element periodic system. The study was conducted using the classroom action research (CAR) method. The instrument in this study consisted of 5 essay questions used to measure student learning outcomes and an observation sheet used to view student activities. The subjects used in the study were students of class X.I of SMA Negeri 1 Manyak Payed consisting of 32 students. The results obtained in this study showed the average student learning activity was $72.30 \%$ in the first cycle and the learning outcomes in the second cycle the average value was $83.07 \%$ an increase of $12.9 \%$. 2. In terms of the process and terms of results an increase in learning outcomes, this can be seen from the test results in the first cycle with an average of 75.3 and the results in the second cycle an average of 82.2 an increase of 6.9 or $8.4 \%$. 3. This proves that by using the Jigsaw method in learning, students can become more active and the activeness done by students is a state that is in accordance with the learning objectives. It was concluded that the Jigsaw method can provide affective results that are very useful for students, where students are educated to be able to take responsibility and work together in positive terms.
\end{abstract}

Keywords: Cooperative Models, Jigsaw, Learning Activities, Learning Outcomes, Periodic System of Elements 


\section{PENDAHULUAN}

Inti dari pendidikan di sekolah adalah proeses belajar mengajar dimana guru merupakan pemegang pemeran utama. Pendidikan merupakan usaha untuk meningkatkan kemampuan anak didik baik kognitif, afektif dan psikomotorik. Salah satu upaya untuk meningkatkan mutu pendidikan di sekolah adalah dengan cara mengembangkan potensi yang dimiliki oleh peserta didik dalam proses belajar mengajar. Setiap guru berusaha mengembangkan sugestik positif pada setiap siswanya didalam kelas untuk memunculkan potensi yang dimiliki siswa.

Kecerdasan dalam hal ini dapat kita artikan sebagai tingkat kemampuan berfikir dan bertindak. Pelajaran kimia terdiri atas bagian-bagian kimia yang dipilih guna menumbuh kembangkan kemampuankemampuan dan membentuk pribadi peserta didik serta berpadu pada perkembangan ilmu pengetahuan dan teknologi.

Salah satu materi yang dapat membentuk pribadi peserta didik adalah materi perkembangan sistem periodik unsur yaitu materi yang berisi teori -teori penemu susunan unsur-unsur yang telah ditemukan di alam dan dibidang ilmu kimia diantaranya teori unsur logam dan non logam, teori triad Doberainer, teori oktaf Newlands, teori mendeelev dan teori system periodic modern yang dipergunakan sampai sekarang. Sub-sub tersebut sangat cocok jika diajarkan dengan menggunakan metode Jigsaw yang memang membagi siswa dalam kelompok dengan materi yang berbeda-beda. Penggunaan metode jigsaw dalam pembelajaran. Pembelajaran ini diharapkan mencapai tujuannya.

Berdasarkan observasi dan wawancara secara personal dengan guru kimia kelas X.1
SMA Negeri 1 Manyak Payed, secara umum siswa mampu menjawab pertanyaan yang bersifat hafalan tetapi tidak bisa menjawab pertanyaan yang bersifat pemahaman dan keterampilan. Untuk mengatasi hal tersebut, guru kimia SMA Negeri 1 Manyak Payed melakukan beberapa perombakan termasuk salah satunya adalah model pembelajara. Salah satu model pembelajaran yang akan digunakan adalah model pembelajaran kooperatif.

Menurut Winata (2003: 125) upaya yang diperlukan guru kreatif utnuk meningkatkan prestasi belajar siswa dengan pembelajaran yang menarik dan disukai oleh peserta didik serta suasana kelas yang lebih efektif dan dibangun sedemikian rupa sehingga dapat diperoleh prestasi belajar yang optimal. Menurut Susilofi model pembelajaran yang mampu mengembangkan dan meningkakan prestasi, kreatifitas, serta kecakapan hidup siswa adalah model pembelajaran kooperatif yang dapat menghantarkan siswa untuk lebih bisa bekerja sama namun tetap mandiri. Salah satu tipe model pembelajaran kooperatif adalah jigsaw yang diharapkan mampu meberikan solusi dalam pembelajaran serta dianggap cocok diterapkan dalam pendidikan di Indonesia.

Berdasarkan uraian di atas maka penulis tertarik melakukan penelitian Tindakan Kelas (PTK) dengan menerapkan metode pembelajaran kooperatif tipe Jigsaw dengan judul penelitian "Upaya Meningkatkan Aktifitas Belajar kimia Melalui Model Pembelajaran Kooperatif Learning Tipe Jigsaw Pada Materi Pokok Perkembangan sitem periodik unsur Di Kelas X.1 SMA Negeri 1 Manyak Payed" agar pembelajaran menjadi lebih baik sehingga aktifitas belajar siswa kelas X.1 SMA Negeri 1 Manyak Payed meningkat. 
e-ISSN: 2721-9038

p-ISSN: 2721-902X

\section{METODE}

Penelitian ini bersifat penelitian tindakan kelas (PTK) yang melibatkan guru bidang studi untuk berkolaborasi melakukan penelitian. Guru bidang studi bertindak sebagai observer dan peneliti sebagai pengajar. Penelitian ini dilakukan dalam beberapa siklus, dengan tiap siklus terdiri dari empat tahap yaitu perencanaan (planning), tindakan (action), pengamatan (observation), refleksi (reflection) (Wardani, 2007: 3). Jika dari siklus I ke siklus II dan seterusnya mengalami perubahan aktifitas belajar yang meningkat pada setiap siklusnya maka upaya dalam meningkatkan aktifitas belajar siswa berhasil dilakukan. Dalam peningkatan aktifitas belajar harus diikuti dengan peningkatan hasil belajar pada tiap siklusnya. Subjek dalam penelitian ini adalah siswa kelas X.1 SMA Negeri 1 Manyak Payed sebanyak 32 orang siswa sedangkan yang menjadi objek dalam penelitian ini adalah peningkatan aktifitas siswa pada materi perkembangan sistem periodik unsur dengan menggunakan model pembelajaran tipe Jigsaw.

Teknik pengumpulan data berdasarkan bentuk data yang ingin diperoleh meliputi tes untuk melihat hasil belajar siswa yang berbentuk essay sebanyak 5 soal, observasi untuk melihat aktivitas siswa dalam belajar menggunakan lembar observasi kegiatan siswa, catatan wawancara yang berguna untuk mendokumentasikan secara tertulis semua peristiwa selama kegiatan dan catatan lapangan untuk pencatatan tertulis mengenai hasil penelitian.

Teknik analisis data yang dilakukan sebagai ukuran berhasil tidaknya peningkatan aktifitas belajar siswa kelas X1 SMA Negeri 1 Manyak Payed dalam pembelajaran menggunakan pembelajaran kooperatif tipe Jigsaw sebagai berikut:

1. Analisis aktifitas belajar siswa
Data hasil observasi berupa data hasil pengamatan aktifitas siswa dianalisis dengan menggunakan rumus yang dikemukakan Wardani (2007: 107) yaitu :

$$
\text { Nilai }=\frac{\sum \text { Skor Perolehan }}{\sum \text { Skor Maksimal }} \times 100 \%
$$

Dengan kriteria sebagai berikut:

$$
\begin{array}{ll}
76 \%-100 \% & =\text { Baik } \\
56 \%-75 \% & =\text { Cukup baik } \\
40 \%-55 \% & =\text { Kurang baik } \\
<40 \% & =\text { Tidak baik }
\end{array}
$$

Untuk penialain aktifitas, siswa dikatakan baik secara klasikal jika telah mencapai $75 \%$.

\section{Analisis hasil belajar}

Analisis yang digunakan dalam penelitian ini adalah analisis hasil belajar siswa berupa hasil dari tes soal sistem persamaan linier sebanyak 5 soal.

Untuk mendapatkan nilai hasil belajar kognitif siswa digunakan rumus :

$$
\text { Nilai }=\frac{\sum \text { skor yang diperoleh }}{\sum \text { skormaksimal }} \times 100 \%
$$

Siswa dengan mendapat nilai < 65\% dinyatakan kesulitan belajar sedangkan siswa yang mendapat nilai lebih besar atau sama dengan 65\% maka dinyatakan telah tuntas belajar. Untuk pembelajaran klasikal, ketuntasan belajar mencapai $85 \%$ dari jumlah siswa yang telah menguasai materi pelajaran 65\% atau lebih. (Mulayasa, 2002: 99).

Untuk mengetahui tingkat penguasaan belajar secara klasikal maka digunakan rumus: Persentase $=$ $\frac{\sum \text { Siswa yang menpadapatkannilai } 65 \%}{\sum \text { Siswa yang mengikuti tes }} \times 100 \%$

Untuk mengetahui tingkat penguasaan materi maka digunakan rumus yang dikemukakan Wardani (2007: 18), yaitu: 
e-ISSN: 2721-9038

p-ISSN: 2721-902X

Tingkat penguasaan $=$

$\frac{\sum \text { jawaban benar }}{\sum \text { jumlah soal }} \times 100 \%$

Dengan kriteria sebagai berikut:

$90 \%-100 \%=$ Baik sekali

$80 \%-89 \%=$ Baik

$70 \%-79 \%=$ Cukup

$<70 \%=$ Kurang

\section{Pengecekan keabsahan}

Untuk mengecek keabsahan data dan objektifitas data dilakukan metode triangulasi, yaitu :

a. Diskusi hasil penelitian dengan pengamat, adalah guru bidang studi kimia SMA Negeri 1 Manyak Payed dan teman sejawat peneliti.

b. Menyesuaikan kenyataan yang terjadi dengan teori-teori para ahli dan membandingkan hasilnya.

\section{Tahap-tahap Penelitian}

1. Persiapan penelitian

Kegiatan pesiapan penelitian antara lain dilakukan sebagai berikut:

a. Mengurus surat ijin penelitian

b. Konsultasi dengan pihak sekolah dalam hal ini Kepala Sekolah SMA Negeri 1 Manyak Payed atau Wakil Kepala Sekolah bagian kurikulum.

c. Menentukan subjek penelitian yang akan dilibatkan pada penelitian yang akan dilakukan dan menyusun perangkat pembelajaran berupa RPP pada materi perkembangan sistem periodik unsur.

2. Pelaksanaan penelitian

Kegiatan pelaksanaan antara lain:

a. Memberikan pretest yang diberikan sebelum pelajaran dimulai. Pretest yang diuji pada masing-masing siswa adalah materi yang telah disusun sesuai dengan penyusunan persiapan pembelajaran materi perkembangan sistem periodik unsur. b. Melaksanakan pembelajaran perkembangan sistem periodik unsur dengan menggunakan metode pembelajaran tipe Jigsaw.

c. Pembelajaran dilakukan dengan membentuk kelompok belajar dan membentuk tim ahli. Setiap tim ahli diberikan materi yang harus dibahas dalam satu kelompok dengan materi yang sama.

d. Tim ahli memberikan hasil diskusi pada anggota kelompok asal. Dengan kata lain, tim ahli akan menjadi guru dalam kelompok asalnya untuk menyampaikan materi yang telah dipelajarinya.

e. Membagikan soal kemudian kelompok belajar diberi tugas untuk menyelesaikan soal materi persamaan gerak dan melakukan observasi selama kegiatan belajar mengajar berlangsung.

f. Postest dilaksanakan, setelah proses pembelajaran berlangsung. Perolehan hasil berupa data yang akan diolah untuk mengetahui hasil belajar yang telah ditempuh oleh siswa dan menganalisis data yang telah terkumpul.

\section{HASIL DAN PEMBAHASAN}

\section{A. Paparan Sebelum Tindakan}

Sebelum dilakukan penelitian, peneliti mengadakan tes awal. Tes ini dimaksudkan untuk mengetahui pemahaman siswa tentang pokok bahasan persamaan gerak. Berdasarkan tes awal, peneliti membagi kelompokkelompok belajar siswa, yang dimulai dengan menyusun nama-nama siswa dari nilai tertinggi hingga nilai terendah. Kemudian nama-nama tersebut dibagi menjadi 8 kelompok yang beranggotakan 4 orang dengan kemampuan yang merata (heterogen).

\section{B. Paparan Hasil Penelitian Tindakan 1. Paparan Siklus I}

Kegiatan yang dilakukan pada siklus I adalah meliputi perencanaan, pelaksanaan, 
observasi, wawancara, dan refleksi. Masingmasing kegiatan diuraikan sebagai berikut :

\section{a. Perencanaan tindakan}

Setelah waktu pelaksanaan ditetapkan, maka peneliti menyiapkan RPP, LKS serta lembar observasi, menyiapkan lembar wawancara, dan soal tes akhir tindakan yang akan diberikan sesudah siklus selesai dilaksanakan.

\section{b. Pelaksanaan tindakan}

Pelaksanaan penelitian dengan melakukan pembelajaran siklus I yang dilakukan pada hari selasa tanggal 18 September 2013. Pembelajaran pada siklus 1 adalah pembelajaran dengan perkembangan sistem periodik unsur. Sesuai dengan rencana pembelajaran maka kegiatan pembelajaran dibagi kepada tiga tahap yaitu tahap awal, tahap inti, dan tahap akhir.

\section{c.Hasil observasi tindakan}

\section{1) Analisis Aktifitas Belajar}

Analisis data hasil observasi yang dilakukan pada peneliti berdasarkan data observasi yang dilakukan pengamat terhadap peneliti dalam menjalankan proses kegiatan belajar mengajar, skor yang didapat peneliti adalah sebagai berikut:

Berdasarkan data observasi yang dilakukan pengamat terhadap peneliti dalam menjalankan proses kegiatan belajar mengajar, skor yang diberikan observer 1 adalah didapat peneliti adalah 48 dengan skor total sebesar 65, maka persentase tingkat keberhasilan penyampaian yang dilakukan peneliti dalam proses belajar mengajar adalah $73,85 \%$ dapat dikategorikan cukup. Skor yang diberikan observer 2 adalah 47 dengan skor total sebesar 65, maka persentase tingkat keberhasilan penyampaian yang dilakukan peneliti dalam proses belajar mengajar adalah $72,30 \%$ dapat dikategorikan cukup. Maka rata-rata aktifitas penyampaian pembelajaran yang dilakukan peneliti adalah $73,07 \%$ dan masih dalam kategori cukup.

Sedangkan aktifitas belajar siswa didapat berdasarkan data observasi yang dilakukan pengamat terhadap siswa dalam menjalankan proses kegiatan belajar mengajar adalah sebagai berikut:

Skor yang diberikan observer 1 adalah didapat peneliti adalah 47 dengan skor total sebesar 65, maka persentase tingkat aktifitas siswa dalam proses belajar mengajar adalah $72,30 \%$ dapat dikategorikan cukup. Skor yang diberikan observer 2 adalah 47 dengan skor total sebesar 65, maka persentase tingkat keberhasilan penyampaian yang dilakukan peneliti dalam proses belajar mengajar adalah $72,30 \%$ dapat dikategorikan cukup. Maka ratarata aktifitas belajar siswa dalam proses pembelajaran adalah $72,30 \%$ dan masih dalam kaegori cukup

\section{2) Analisis Hasil Belajar Siswa}

Setelah mengakhiri pelajaran, peneliti memberikan tes untuk melihat tingkat keberhasilan kegiatan belajar mengajar yang dilakukan peneliti pada siswa kelas X1 SMA Negeri 1 Manyak payed yang melakukan pembelajaran pokok bahasan perkembangan system periodic unsur dengan menggunakan metode pembelajaran tipe Jigsaw.

Dari tes siklus I yang terdapat pada lampiran diketahui bahwa jumlah siswa yang memperoleh skor $\geq 65$ yang merupakan KKM dari mata pelajaran kimia berjumlah 23 orang siswa dari 32 orang siswa, maka persentase siswa yang memperoleh skor $\geq 65$ adalah $75 \%$. Dengan demikian dari segi hasil belum memenuhi kriteria yang sudah ditentukan dimana ketuntasan klasikal siswa harus mencapai ketuntasan sebesar $85 \%$ sehingga pembelajaran dianggap belum berhasil sehingga harus dilakukan pembelajaran selanjutnya, yaitu dilakukan pembelajaran siklus II. 
e-ISSN: 2721-9038

p-ISSN: 2721-902X

\section{d. Hasil wawancara tindakan}

wawancara dimaksudkan seberapa besar pemahaman siswa terhadap materi perkembangan system periodik unsur yang dipelajari dengan menggunakan metode pembelajaran tipe Jigsaw. Oleh karena itu pertanyaan yang ditanyakan kepada siswa tentang kesulitan siswa dalam mengerjakan LKS, dan tes akhir siklus.

\section{e. Refleksi}

Berdasarkan hasil tes, wawancara, dan pengamatan terhadap pelaksanaan pembelajaran dan objek penelitian pada siklus I, maka dapat disimpulkan bahwa :

1) Dari segi proses

Proses siklus I menunjukkan bahwa siswa terlihat aktif dalam pembelajaran, rata-rata persentase keaktifan siswa adalah $72,30 \%$ yang berada dalam katagori cukup dan belum memenuhi kriteria ketuntasan yaitu $75 \%$. Siswa juga saling bekerja sama dalam menyelesaikan tugas kelompoknya, dilihat dari hasil observasi maupun hasil wawancara meskipun masih terdapat beberapa siswa yang masih mendapat kesulitan dalam memecahkan materi yang berkaitan dengan materi pokok pembelajaran yaitu perkembangan system periodic unsur

2) Dari segi hasil

Pada siklus I pembelajaran yang disampaikan tidak berhsil, hal ini dapat dilihat dari perolehan skor hasil tes siswa dimana jumlah siswa yang memperoleh skor $\geq 65$ adalah berjumlah 24 orang siswa, maka persentase siswa yang memperoleh skor $\geq 65$ adalah $75 \%$ Dengan demikian dari segi hasil dikatakan belum memadai dikarenakan belum memenuhi kriteria yang sudah ditentukan yaitu $85 \%$.

Dengan demikian, berdasarkan paparan data dari hasil pembelajaran pada siklus I dapat disimpulkan bahwa pembelajaran belum berhasil dari segi proses dan segi hasil sehingga tujuan pembelajaran belum tercapai. Dikarenakan pembelajaran pada siklus I belum dapat dikatakan berhasil maka harus dilanjutkan pada siklus berikutnya yaitu siklus II.

\section{Paparan Siklus II}

Kegiatan yang dilakukan pada siklus II adalah kegiatan lanjutan pada siklus I yang meliputi perencanaan, pelaksanaan, observasi, wawancara, dan refleksi. Masing-masing kegiatan diuraikan sebagai berikut :

\section{a. Perencanaan tindakan}

Setelah waktu pelaksanaan ditetapkan, maka yang perlu dipersiapakan adalah RPP, LKS, menyiapkan lembar observasi, menyiapkan lembar wawancara, dan soal tes akhir tindakan yang akan diberikan sesudah siklus selesai dilaksanakan.

\section{b. Pelaksanaan tindakan}

Pembelajaran pada siklus II dilaksanakan pada hari selasa tanggal 25 Oktober 2013. Materi yang diberikan adalah perkembangan sistem periodik unsur. Sesuai dengan rencana pembelajaran maka kegiatan pembelajaran dibagi kepada tiga tahap yaitu tahap awal, tahap inti, dan tahap akhir.

\section{c. Hasil observasi tindakan}

\section{1) Analisis Aktifitas Belajar}

Berdasarkan data observasi peneliti menunjukkan skor yang diperoleh observer 1 adalah 56 dengan skor total sebesar 65, maka persentase tingkat keberhasilan penyampaian dalam proses belajar mengajar adalah $86,15 \%$ dengan kategori baik. Skor yang diberikan observer 2 adalah 55 dengan skor total sebesar 65, dengan persentase $84,62 \%$ dapat dikategorikan baik. Maka rata-rata aktifitas penyampaian pembelajaran yang dilakukan peneliti adalah $85,38 \%$ dan masih dalam kaegori baik. 
Sedangkan aktifitas belajar siswa didapat berdasarkan data observasi yang dilakukan pengamat terhadap siswa dalam menjalankan proses kegiatan belajar mengajar adalah sebagai berikut:

Skor yang diberikan observer 1 adalah 56 dengan skor total sebesar 65 , maka persentase tingkat aktifitas siswa dalam proses belajar mengajar 6,15\% dengan kategori baik. Kemudian skor yang diberikan observer 2 adalah 54 dengan skor total sebesar 65, maka persentase tingkat keberhasilan penyampaian yang dilakukan peneliti dalam proses belajar mengajar adalah 86,15\% 83,07\% daengan kategori baik. Skor yang diberikan observer 2 adalah 54 dengan skor total sebesar 65, maka persentase tingkat keberhasilan penyampaian yang dilakukan peneliti dalam proses belajar mengajar adalah 83,07\% dapat dikategorikan baik. Maka rata-rata aktifitas belajar siswa dalam proses pembelajaran adalah $84,61 \%$ dalam kaegori baik.

\section{2) Analisis Hasil Belajar Siswa}

Setelah mengakhiri pelajaran, peneliti memberikan tes untuk melihat tingkat keberhasilan kegiatan belajar mengajar pada siswa kelas X-1 SMA Negeri 1 Manyak Payed pada materi perkembangan system periodik unsur dengan menggunakan metode pembelajaran tipe Jigsaw.

Siklus II yang terdapat pada lampiran diketahui bahwa jumlah siswa yang memperoleh skor $\geq 65$ yang merupakan KKM dari mata pelajaran kimia. Maka, persentase siswa yang memperoleh skor $\geq 65$ adalah 90,6\%. Dengan demikian dari segi hasil sudah memenuhi kriteria yang sudah ditentukan dimana ketuntasan klasikal siswa harus mencapai ketuntasan sebesar $85 \%$ sehingga pembelajaran dianggap sudah berhasil sehingga tidak perlu dilakukan dilakukan pembelajaran selanjutnya.

\section{d. Hasil wawancara tindakan}

Kegiatan wawancara dimaksudkan untuk mengetahui seberapa besar pengetahuan siswa terhadap materi perkembangan system periodik unsur yang dipelajari dengan menggunakan metode pembelajaran tipe Jigsaw pada siklus II. Oleh karena itu pertanyaan yang ditanyakan kepada siswa tentang kesulitan siswa dalam mengerjakan LKS, dan tes akhir siklus II.

Dari hasil wawancara pada siklus pertama diketahui bahwa kesulitan siswa yang terjadi pada siklus I sudah dapat sedikit diatasi, dimana siswa sudah dapat menjelaskan perbedaan tiap teori pada perkembangan system periodic unsur serta dapat menjelaskan kekurangan dari masing-masing teori tersebut.

\section{e. Refleksi}

Berdasarkan hasil tes, wawancara, dan pengamatan terhadap pelaksanaan pembelajaran dan objek penelitian pada siklus II, maka dapat disimpulkan bahwa :

1) Dari segi proses

Pada siklus II terlihat siswa aktif dalam pembelajaran, rata-rata persentase keaktifan siswa adalah $83,07 \%$ yang berada dalam katagori baik dan sudah memenuhi kriteria ketuntasan yaitu $75 \%$

2) Dari segi hasil

Pada siklus II pembelajaran telah berhasil, hal ini dapat dilihat dari hasil skor tes siswa dimana jumlah siswa yang memperoleh skor $\geq$ 65 berjumlah 29 orang siswa dengan persentase adalah 90,6\% Dengan demikian dari segi hasil dikatakan sudah memadai dikarenakan sudah mencapai kriteria yang sudah ditentukan yaitu $85 \%$.

Dengan demikian, berdasarkan paparan data dari hasil pembelajaran pada siklus II dapat disimpulkan bahwa pembelajaran perkembangan system periodic unsur pada siklus II dengan menggunakan metode pembelajaran tipe Jigsaw sudah berhasil dari 
e-ISSN: 2721-9038

p-ISSN: 2721-902X

segi hasil dan segi proses, dengan demikian tujuan pembelajaran sudah tercapai dan pembelajaran pada siklus II dapat dikatakan berhasil.

\section{PEMBAHASAN}

Setelah dilakukan pembelajaran dalam dua siklus yaitu siklus I dan siklus II data didapat bahwa terjadi peningkatan aktifitas belajar dan hasil belajar pada siklus I dan siklus II. Hal ini dapat dilihat pada rata-rata persentase aktifitas belajar siswa pada siklus I adalah $72,30 \%$ dan pada siklus II meningkat $12,9 \%$ yaitu $83,07 \%$. Sedangkan nilai tes pada siklus I yaitu 75,3 meningkat $8,4 \%$ menjadi 82,2 pada siklus II, hal ini menunjukkan peningkatan hasil belajar yang terjadi pada tiap siklus.

Dilihat dari segi hasil dan keaktifan siswa dalam belajar, dapat dikatakan tuntas. Yang mana pada siklus I terdapat 24 orang siswa yang mencapai ketuntasan belajar yaitu $75 \%$, sedangkan pada siklus II meningkat menjadi 29 orang siswa yang mencapai ketuntasan yaitu 90,6\%. Dari segi proses, terjadi peningkatan kegiatan pembelajaran dimana pada siklus I kegiatan pembelajaran berada pada kriteria cukup. Sedangkan pada siklus II kegiatan belajar mengajar masuk ke dalam kriteria baik, hal ini juga menunjukkan peningkatan hasil pembelajaran dari segi proses.

Dari uraian hasil penelitian diketahui bahwasannya pembelajaran dengan menggunakan metode jigsaw ternyata dapat meningkatkan aktifitas belajar, hal ini terlihat dari hasil observasi dari segi proses yang meningkat pada tiap siklusnya. Dari kedua siklus terlihat bahwa muncul ketertarikan siswa dan sikap positif siswa terhadap materi yang diajarkan. Pembelajaran dengan menggunakan metode Jigsaw melatih siswa untuk mandiri serta dapat berbagi ilmu.
Pembelajaran dikatakan berhasil jika pembelajaran tersebut dapat dilakukan secara merata, menghasilkan output yang berkualitas dan berkuantitas baik, serta menghasilkan perkembangan pada siswa. Dengan demikian pembelajaran dengan menggunakan metode Jigsaw pada materi perkembangan sistem periodik unsur di kelas X1 SMA Negeri 1 Manyak payed dikatakan berhasil dan dapat meningkatkan aktifitas belajara siswa.

\section{KESIMPULAN}

Berdasarkan analisis data yang didapat dari hasil penelitian, maka dapat disimpulkan :

1. Pembelajaran dengan menggunakan metode jigsaw pada materi pokok perkembangan sistem periodik unsur dapat meningkatkan aktifitas belajar siswa kelas X.1 SMA Negeri 1 Manyak Payed. Hal ini dapat dilihat pada hasil siklus I dengan rata-rata $72.30 \%$ dan hasil pada siklus II rataratanya $83,07 \%$ terjadi peningkatan $12,9 \%$.

2. Dari segi proses dan segi hasil terjadi pengingkatan hasil belajar, hal ini dapat dilihat dari hasil tes pada siklus I dengan rata-ratanya75,3 dan hasil pada siklus II rata-ratanya 82,2 terjadi peningkatan sebesar 6,9 atau $8,4 \%$.

3. Dengan menggunakan metode Jigsaw dalam pembelajaran, siswa dapat menjadi lebih aktif dan keaktifan yang dilakukan siswa adalah keadaan yang sesuai dengan tujuan pembelajaran.

4. Metode Jigsaw dapat memberikan hasil afektif yang sangat berguna bagi anak didik, dimana siswa dididik untuk dapat bertanggung jawab dan bekerja sama dalam hal yang positif.

\section{SARAN}

Berdasarkan kesimpulan di atas, maka terdapat beberapa saran yang ingin disampaikan oleh peneliti, yaitu : 
1. Guru bidang studi dapat menggunakan metode ini dalam kegiatan belajar mengajar, dan dapat digabungkn dengan metode yang lain untuk hasil yang lebih maksimal.

2. Guru dalam proses belajar hendaknya mempersiapkan beberapa siswa yang memiliki kemampuan lebih daripada temannya untuk dibimbing khusus menjadi team ahli yang nantinya dapat meringankan tugas guru dalam proses belajar mengajar.

\section{DAFTAR PUSTAKA}

Igak Wardani. 2007. Penelitian Tindakan Kelas. Jakarta: Universitas Terbuka

Mulyasa. 2002. Manajemen Berbasis Sekolah. Bandung: Rosdakarya

Susilofi. 2010. Meningkatkan Hasil Belajar Siswa Dengan Menggunakan Metode Jigsaw. http://www.wordpres.com, diakses tanggal 30 Januari 2010.

Winata putra, Udin. Dkk. 2003. Strategi Belajar Mengajar. Jakarta: Depdikbud. 